\title{
Studying the Impact of E-Service Quality on E-Loyalty of Customers in the Area of E-Banking Services
}

\author{
Naser Asgari ${ }^{1}$, Mohamad Hassan Ahmadi ${ }^{2}$, Mehdi Shamlou ${ }^{3}$, Atefe Rashid Farokhi ${ }^{4}$ \& Milad Farzin ${ }^{5}$ \\ ${ }^{1}$ Assistant Professor in Public Administration, Faculty of Management Department, Shahid Sattari Aviation \\ University, Tehran, Iran \\ ${ }^{2}$ M.A. in IT Administration, Faculty of Accountancy \& Management Department, Shahid Beheshti, Iran \\ ${ }^{3}$ M.A. in MBA, Faculty of Payame Noor Karaj, Iran \\ ${ }^{4}$ M.A. in Business Administration, Faculty of Payame Noor Tehran, Iran \\ ${ }^{5}$ Azad University of Babol, Iran \\ Correspondence: Naser Asgari, Faculty of Management Department, Shahid Sattari Aviation University, Tehran, \\ Iran. E-mail: drasgari.n@gmail.com
}

$\begin{aligned} & \text { Received: March 6, } 2014 \\ & \text { Accepted: April 30, } 2014 \quad \text { Online Published: May 27, } 2014 \\ & \text { doi:10.5539/jms.v4n2p126 }\end{aligned} \quad$ URL: http://dx.doi.org/10.5539/jms.v4n2p126

\begin{abstract}
Customer loyalty is one of the ways to build a competitive advantage and important issue in e-banking debate to achieve higher profits. While customers are less loyal to their banks and they use e-services of various banks. Despite the importance of e-loyalty, fewer banks appear to be successful in creating e-loyalty of customer. Also, there is a little knowledge about mechanisms to create customer loyalty on the Internet. The purpose of this study is better understanding the impact of e-service quality on e-loyalty of bank customers. In this regard, Hekmat Iranian Bank has been studied. In this study we made use of simple random sampling (SRS). In this method each of elements in the population has an equal chance of being selected. In this research, 384 people were considered among all customers of Hekmat Iranian bank. We also concluded that variables of completing the banking services, security, privacy and accountability and designing website will have a significant positive impact on e-loyalty and finally recommendations are presented according to the research findings.
\end{abstract}

Keywords: e-service quality, e-loyalty, e-banking

\section{Introduction}

Nowadays, fewer customers are loyal to their banks and use of electronic services of various banks (Seyed Javadin \& Yousefi, 2001). As Richheld and Schefter (2000) mentioned, a secret weapon on the web is to develop loyal customers, especially when the competition is just a mouse click, e-loyalty seems necessary for both economic and competitive aspects for online banks ( $\mathrm{Li}, 2009)$. It should be considered that the context of e-loyalty is different from its common context in the traditional sense (Lake, 2009) and changes with the addition of a new banking system will create a different way of loyalty (Nour, 2005). The issue of developing loyalty in cyberspace where customers are often forced to make a decision to purchase with a limited amount of information is very complex and more difficult than the real world (Lee, 2009). According to the rules, in this competitive environment of banks and financial institutions 'activity, customers have more choices (Kazemi \& Khojaste, 2010), and the only way to retain customers is to establish and strengthen customer loyalty. Active sites in the field of e-commerce need to think about ways to reduce worries and to increase confidence and satisfaction and finally loyalty of the customers. Such measures would increase the tendency to accelerate trend to e-commerce and at the same time it benefits the seller and buyer. According to Porter's theory (1980), there are two main ways to create a competitive advantage: to offer affordable products and services or to make a distinction by providing a valuable and unique ways. One way to build competitive advantage is customer loyalty and is an important topic in studying the markets and stores (Park \& Kim, 2003; Yang \& Peterson, 2004). E-loyal customer can increase the profitability for store through long -term commitment and can reduce the cost of acquiring new customers (Reichheld et al., 2000). E-loyal customers are not the ones who are looking for the lowest prices, but those who look for prices to be more worthy. They also try to push customers into the store 
and thus they provide potentially rich resources of benefits. In addition, e-loyal customers purchase more than new customers and they can receive services with lower operating costs (Van Riel et al., 2001).

Therefore, even if the costs of building the loyalty were more than the cost of physical shops, the greater will be the linking profit growth rate (Reich Held \& Schefter, 2000). Despite the importance of e-loyalty, few banks appear to be successful in building e-loyalty of customer. In addition, there is little knowledge about the mechanism of building loyalty of customers in the Internet (Reibings et al., 2004).

If we consider the effective communication as a key to successful sales, customer loyalty should be taken into account as the nature and base of making any successful relationship in any area of ruling, life and business .If we ask the sellers in different fields and heads of great sales organization about the reasons of their success, without a doubt, they will introduce customer loyalty of the most important and strategic factors in this context (ShirKhodaii, 2005). Generally, one of the main challenges for any business is to build trust with customers, improving their satisfaction level and to make them become loyal customers. In this regard, to build trust with customers in Internet businesses has become a key element for success, because of novelty of the environment for customers and the lack of physical interaction. In fact, the client in this system should forget about habits and trends to which get accustomed traditionally over the years and to interact with the seller in new ways. However, sometimes the process of attracting online customers and providing services or goods to them is the same as the traditional process in some ways, but in many ways they are different. Global development of the Internet has led to make e-commerce. E-commerce is improved quickly because of freedom, speed, anonymity, being digital and universal access that are features of the Internet. E-commerce makes it easy to have real-time business activities, such as advertising, searching and researching, sourcing, negotiation, clearance sale, ordering and payment (Heskett, 1997).

According to a growing statistic of the world trend to web-based business, there is an important component of e-services that has been approved as an undeniable need, and to attract more customers and to expand and to diversify their services business organizations rapidly synchronized and integrated themselves with information and communication technologies and every organization strives to provide the new service of electronic service package becomes a pioneer in this field (Elmiye, 2008). E-loyal customers purchase more than new customers and they can receive services with lower operating costs (van Riel et al., 2001); hence, even if the costs of building the loyalty was more than the cost of physical shops, the greater will be the linking profit growth rate (Reich Held \& Schefter, 2000). To Hekmat Iranian bank as a bank to provide-banking services to customers it is reasonable to retain customers rather than looking for new customers, because the cost to attract new customer is higher than retain current customer which shows the necessity of promoting electronic banking services. One of the issues that can play an important role for the supplying company in this area is the quality of service offered electronically. Thus, paying attention to the quality of online services by financial companies can play an important role in building customer loyalty to use of these services. As a result, we will study the relationship of e-service quality effect on e-loyalty of customers in e-banking of Hekmat Iranian bank in Tehran.

Research purposes:

1) To provide a comprehensive model of e-service quality and to evaluate e-service quality dimensions on consumer confidence;

2) To evaluate the impact of e-services accountability on customers' trust to e-services;

3) To evaluate the impact of completing e-services on customer trust to e-services;

4) To evaluate the impact of security / privacy of e-services on customers trust to e-services;

5) To evaluate the impact of ease in using e-services on customer trust to e-services;

6) To evaluate the impact of website design on e-services and on customer trust to e-services;

7) To evaluate the impact of e-service efficiency on customer trust to e-services.

Research questions:

1) Does the e-service quality have a positive and significant impact on the customer confidence to e-services?

2) Does the e-service accountability have a positive and significant impact on the customer confidence to e-services?

3) Does the e-service completion have a positive and significant impact on the customer confidence to e-services? 
4) Does the security/privacy of e-service have a positive and significant Impact on the customer confidence to e-services?

5) Does the ease of using e-service have a positive and significant impact on customer confidence to e-service?

6) Does the efficiency of e-services have a positive and significant impact on customer confidence to e-services?

7) Does the website design have a positive and significant impact on customer confidence to e-services?

\section{Theoretical Discussion}

\subsection{E-Service Quality}

One of the basic definitions of e-service quality is by Zeithmal and colleagues (2002). From these authors' view, the e-service quality is a field in which there is a possibility to provide efficient and effective services to users through electronic media. Parasuaman and colleagues (2005) indicated in their study that the users' perceptions of service quality in an electronic media are very different in comparison with another media, because according to the different opinions and perceptions of people about technology, the acceptance and application of technologies is different. Zeithmal and his colleagues defined e-service quality as ranges on which electronic media leads to the ease of efficient and effective shopping, purchasing and delivery of real products and the review of literature and services (Zeithmal et al., 2000). In another definition, the feature of the fulfillment of customer needs efficiently and effectively called the electronic service quality (Fenglin \& Zakson, 2008). E-service quality in terms of Santos perspective (2003) is the general perceptions, judgments and evaluation of customers about services that will provide from the electronic media (Edwu et al., 2010).

E-service quality recommends the pragmatic interpretation of the quality and customer satisfaction as the most important factor confirming the quality level of service. The customer needs to determine the expected service quality levels and high levels of service quality can be considered as a competitive advantage. Nowadays, in parallel to awareness increasing of consumers of the services provided by organizations and standards related to their expectations of the service also have been increased (Abtahi \& Meratnia, 2008). Parasuraman et al. (2002) argued that e-services have two major advantages: "informational output and transactional output"; therefore, it is not surprising that online customers captured by virtual environment in looking for these both qualities (Barrutia \& Gilsanse, 2009).

\subsection{E-Loyalty}

Loyalty concept in Internet is interpreted as the e-loyalty and it is a relatively new concept (Lake, 2009) and is considered a branch of loyalty concept that is implemented in commerce (Ela Gaga \& Nour, 2011). In fact, the concept of e-loyalty extends traditional loyalty to an online consumer behavior. E-loyalty is defined as the willingness to observe and to revisit a website or to make a transaction in the future (Lee, 2009). Although the theoretical foundations of traditional loyalty and new defined phenomenon as e-loyalty are generally similar, they have unique aspects associated with Internet-based marketing and buyer behavior (Chang \& Chen, 2008). Therefore, e-loyalty is different from the loyalty without "E" (Electronic), and the emphasis is on loyalty of those customers that trade and commerce on the Internet. Since the Internet markets are different from the traditional markets in terms of lacking human identity and physical features, online customer loyalty should also be considered differently (Sun \& Li, 2005). E-loyalty is defined as a perceived tendency to visit or reuse of a website and purchasing from that website in the future (Keyr et al., 2009). Anderson, Serini and Asan (2003) have defined e-loyalty as a favorable attitude and customer commitment toward an electronic business resulting in repeating shopping behavior (Leung et al., 2011).

\subsection{Electronic Banking}

Electronic banking is a term used for modern banking system (Ota, 2010). Electronic banking is a special type of banking services to provide its clients services they use an electronic environment (media) such as the Internet. In this type of banking, the whole operations including receiving or depositing money, signature verification, inventory and other considerations are conducted as the Internet banking operations. Electronic banking and the World Wide Web (WWW) made banks to use electronic channels increasingly for receiving instructions and delivering their products and services to customers in the second half of 1990 (Salehi \& Alipour, 2010). E-banking is a new way for customers to access their account, to pay their bills, to take control of their money and to make use of the various services. Indeed, the ultimate aim of organizing the electronic banking system is to minimize all references to the location of bank branches to do banking services and if possible remove them all. Electronic banking allows bank customers with convenient access to manage their financial affairs to put them to the least inconvenience possible, so that a quick and convenient way was provided to perform a variety 
of banking transactions through the Internet Banking website, from the house, office, or elsewhere that is available 24/7 (B.Faziharrowdin, 2010).

\subsection{Experimental Background}

While the dimensions of electronic service quality is considered to be a direct factor of e-loyalty sometimes (Srinewson, 2002), most of their researches can be considered as a precedent and background for electronic consent (Van Riley, 2004), it means that the consent is seen as an intermediary of a relationship between the quality and satisfaction (Karona, 2002). However, there is no consensus on the exact number or nature of quality that customers consider when evaluating e-services (Srinewson et al., 2002; Zeithmal et al., 2002). There are evidences that show a positive relationship between trust to e-provider and e-loyalty that are assessed in terms of purchase increase (Gefen, 2000) and purchase intentions (Pavlou, 2003) or buy back (Penn et al., 2002).The lack of confidence commonly can be considered as a proof of not purchasing from an online business (Lee \& Turban, 2001). To compare with the findings of traditional loyalty, positive word is also expected that results from confidence (Geramler \& Brown, 1999). The service quality has a deep impact on satisfaction and loyalty of customers and in fact is the result of a comparison by our customers between the expectations of services and their perceptions (Karoana, 2002). E-SERVEQUAL has been introduced by Zeithmal and colleagues (2000) to measure the quality of e-services. They have identified size dimensions for online service quality through interviews with a sample groups that include efficiency, reliability, completion of service, privacy, accountability, compensation and contact.

They have identified four dimensions of efficiency, reliability; service completion and privacy as the core of E-SERVEQUAL scale are used to measure customer perception of provided service quality by electronic services. They also found that three of these dimensions are significant only when online customers have a question or a problem. These dimensions are: accountability, compensation, and contact. Venerile et al. (2001) have introduced six dimensions as e-service quality dimensions by study on the quality site portal and tested the impact of each on e-loyalty that are convenience, web site design, ease of access, financial security, and commitment and enjoyment (Rile et al., 2001). Fifteen dimensions of online quality were proposed by Medov and Medov (2002) that are: performance, features, structure, aesthetics, reliability, storage capacity, reliability of service, security and system availability, reliability, storage capacity, service ability, security and system access, confidence, accountability, differentiation and adaptation of service/product, web store policies, reputation, assurance and empathy (Medov \& Medov, 2002). Kayer et al. (2006) considered five dimensions as effective factors on e-loyalty that are: understanding usability, understanding ease of use, reliability, enjoyment, understanding social presence. They also examined the relationship between confidence and loyalty and after analyzing the results found that there is a positive and direct relationship between confidence and loyalty (Kayer et al., 2006).

Several other studies have also recognized and acknowledged some different factors having impact on e-loyalty. Fragata and Moustakas (2012) concluded that E-banking quality has strong impact on e-loyalty via the mediating effect of trust and that switching costs have strong impact on e-loyalty. In addition, Olalekan (2011) concluded that gender differences in e-banking patronage and also satisfaction is found to be low which calls for improvement in service delivery in terms of timeliness and consistency in standards. Yee and Faaziharuddin (2010) also found that Trust, habit and reputation are found to have a significant influence on E-Loyalty towards individual Internet banking websites, reputation is the strongest influence. Service quality is found to be an important factor in influencing the adoption of the technology, but did not have a significant influence in retention of customers.

Another related study is Ariff et al. (2014) which found that assurance-fulfillment, efficiency-system availability; privacy, contact-responsiveness and website aesthetics and guide constitute e-SQ for the internet banking service, indicating some modification to the E-SERVQUAL is required when it is used to measure e-SQ for the service. Website aesthetics and Guide, Efficiency-System availability and Contact-Responsiveness of the Internet banking e-SQ were positively affected e-Satisfaction. E-Satisfaction was positively significant to e-Loyalty. E-Satisfaction was found to partially mediate the relationship of Website aesthetics and guide of e-SQ and customer e-Loyalty. The result highlighted that attractiveness and appearance of banks' websites, and the information and guidance provide by the websites are important features to Internet banking users. This finding reflected that in internet banking, beside the technical and functionality aspects of banks' websites e-SQ, such as efficiency, fulfillment and system availability, the aesthetic value and proper guidance of the websites are also crucial to ensure quality of e-SQ that will lead to e-Satisfaction and e-Loyalty.

As noted before, the purpose of this study is better understanding the impact of e-service quality on e-loyalty of 
bank customers. Among various determinant factors of e-loyalty, the effect of some critical factors will be studied that may have considerable effects in e-banking services. The conceptual model of the relationships among these factors and e-loyalty is presented in the figure 1 .

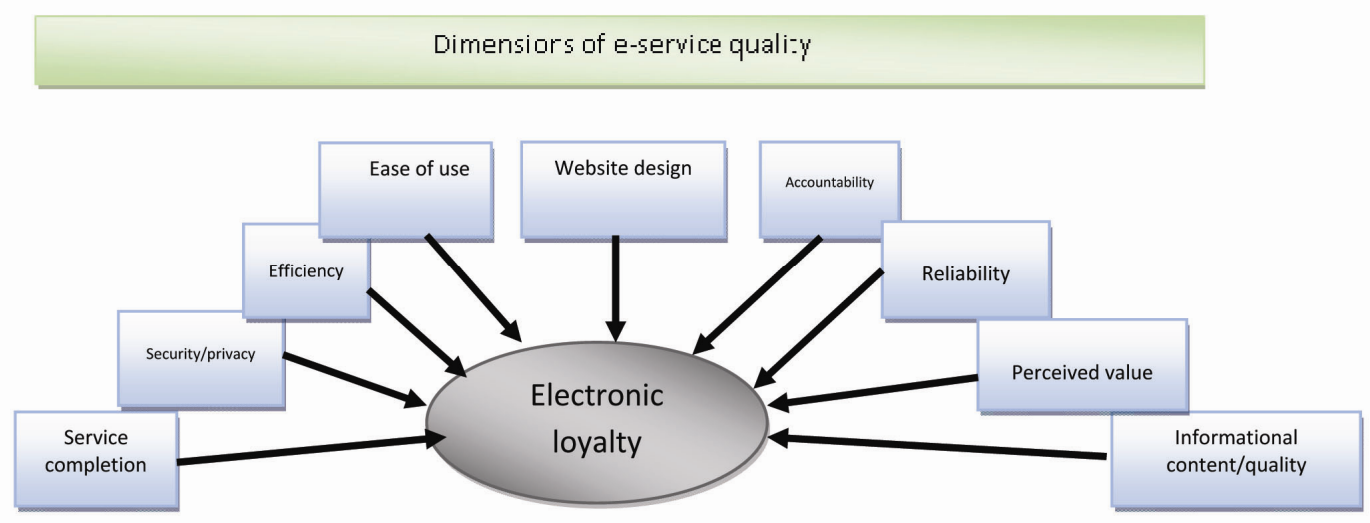

Figure 1. Conceptual model of e-service quality dimensions impact on e-loyalty

Source: Kayer et al., 2006; Parasuraman, 2002; Richheld, 1996; Young, 2004.

The independent variable dimensions of e-service quality include accountability, website design, ease of use, efficiency, security / privacy and the completion of perceived value about websites, reliability and informational content/quality that influence on dependent variable of e-loyalty that the impact of each dimension is presented in this research.

\section{Research Methodology}

\subsection{Population and Statistical Sample}

The purpose of this study is practical and for data collection the descriptive survey method is used. This study is a compilation of various studies and research models of e-service such as Kayer et al. (2006), Parasuraman (2002), Richheld (1996) and Young (2004) that are the strongest researches in e-service field and they have been considered as test criteria of forming components of research. The Subject territory of this study is also about evaluating the impact of e-service quality on building costumer in Hekmat Iranian bank (Tehran branch). The statistical population of this survey is all bank customers that are estimated about 170 thousand people in initial estimation. According to infinite statistical population, the best way to select statistical sample is to use Cochran formula (the formula to define sample size in infinite space). Based on unknown population variance, the results of using these tools in confidence level of $\% 95$ leads to choose a sample size of 384 people for this research.

According to statistical population in this study, level of study and no difference among statistical population members, the random sampling method is used. In simple random sampling of the population, each element has an equal opportunity. The main tool for data collection in this study is a questionnaire (field section), that in addition to it, there are electronic resources, books, articles, researches and other relevant written sources used to complete the needed research information (a library section). The validity of the questionnaire was reviewed and approved by using standard tests and expert opinions. The reliability of the questionnaire was calculated 0.895 using the Cronbach's alpha. Obtained data were analyzed using linear regression analysis tool (spss software).

\subsection{Data Analysis}

Table 1 presents the relationship between two variables of e-service quality and customer confidence to e-service: 
Table 1 . The relationship between two variables of e-service quality and customer loyalty to e-services

\begin{tabular}{lllllllll}
\hline $\begin{array}{l}\text { Independent } \\
\text { variable }\end{array}$ & $\begin{array}{l}\text { Dependent } \\
\text { variable }\end{array}$ & $\begin{array}{l}\text { Correlation } \\
\text { coefficient }\end{array}$ & $\mathrm{R}$ & $\begin{array}{l}\mathrm{R} \\
\text { SQUARE }\end{array}$ & $\begin{array}{l}\mathrm{B} \\
\text { standard }\end{array}$ & $\begin{array}{l}\text { Nonstandard } \\
\text { coefficient B }\end{array}$ & T-test & Sig \\
\hline e-service quality & e-loyalty & 0.712 & 0.804 & 0.428 & 0.804 & 0.732 & 17.745 & 0.001 \\
\hline
\end{tabular}

The significance level is 0.000 and is smaller than the error value of 0.05 ; this means that there is no correlation between the two variables. The direct and high correlations between e-service quality and customer loyalty to e-services. Generally, the level of significance is equal to 0.000 and less than 0.05 and it is concluded that there is a linear relationship between e-service quality and e-loyalty that this value is equal to 0.928 and e-service quality impact on e-loyalty of customers is also equal to 0.655 .

Table 2. The significance test of regression coefficients

\begin{tabular}{|c|c|c|c|c|c|}
\hline \multirow{2}{*}{ model } & \multicolumn{2}{|c|}{ Non-standard coefficient } & \multirow{2}{*}{$\begin{array}{l}\text { Standardized coefficient } \\
\text { Beta }\end{array}$} & \multirow{2}{*}{$\mathrm{T}$} & \multirow{2}{*}{ Significant level } \\
\hline & $\mathrm{B}$ & Std.Errot & & & \\
\hline Constant & 0.135 & 0.045 & & 2.169 & 0.002 \\
\hline accountability & 0.321 & 0.055 & 0.124 & 2.254 & 0.000 \\
\hline Service completion & 0.301 & 0.042 & 0.241 & 7.047 & 0.003 \\
\hline Security/privacy & 0.214 & 0.014 & 0.142 & 8.657 & 0.000 \\
\hline Ease of use & 0.314 & 0.025 & 0.058 & 3.420 & 0.005 \\
\hline efficiency & 0.287 & 0.057 & 0.241 & 4.309 & 0.001 \\
\hline Web site design & 0.368 & 0.036 & 0.218 & 5.069 & 0.001 \\
\hline $\begin{array}{l}\text { Informational content/ } \\
\text { quality }\end{array}$ & 0.258 & 0.027 & 0.238 & 3.987 & 0.000 \\
\hline reliability & 0.324 & 0.029 & 0.057 & 4.379 & 0.000 \\
\hline Perceived value & 0.24141 & 0.016 & 0.087 & 2.258 & 0.004 \\
\hline
\end{tabular}

Because the significant level is smaller than the error level of 0.05 (absolute t-value is greater than 1.96) with $95 \%$ confidence interval we concluded $\mathrm{H}$ 1, therefore the response variables of accountability, service completion, security/privacy and website design remain in model and the coefficients are 0.123 and 0.262 and 0.219 and 0.509 , respectively. We also concluded the above variables have a positive and significant (standardized beta coefficients). In equation below $\mathrm{Y} 1$ is e-loyalty and $\mathrm{X} 1$ is accountability, $\mathrm{X} 2$ is service completion, $\mathrm{X} 3$ security, $\mathrm{X} 4$ ease of use, X5 efficiency, X6 website design, X7 informational content/quality, X8 reliability and X9 reliability is perceived value.

$$
Y 1=0.135+0.321 X 1+0.301 X 2+0.214 X 3+0.314 X 4+0.287 X 5+368 X 6+258 X 7+324 X 8+241 X 9
$$

To check the existing condition of two main indicators of e-service quality and e-loyalty in test population, single-sample Wilcoxon test has been done and data are briefly outlined in table 3 .

Table 3. Single-sample Wilcoxon test on two indicators of electronic service quality and electronic confidence

\begin{tabular}{lllll}
\hline Variable & Significance level & Error level & $\begin{array}{l}\text { Hypothesis } \\
\text { approval }\end{array}$ & Conclusion \\
\hline e-service quality & 0.000 & 0.05 & H1 & desirable \\
e-loyalty & 0.000 & 0.05 & H1 & desirable \\
\hline
\end{tabular}

Because the level of significance for both the e-service quality and e-loyalty is smaller than 0.05 we concluded the $\mathrm{H} 1$ and this means both indicators of e-service quality and e-loyalty are desirable.

\section{Conclusions and Recommendations}

Generally the variable of e-service quality dimension has a positive and impact on e-loyalty, as well as variables of accountability, security/privacy and service completion and website design, and because the variables of efficiency and ease of use do not have a positive and significant relationship with e-loyalty are removed from model. The e-service quality indicator has a relatively desirable condition in population, so of six defined dimensions for this indicator, accountability variable has no relatively desirable condition in population, the ease 
of use and security/privacy dimensions have the highest rank and then efficiency, website design, service completion and accountability are categorized in existing condition and also e-loyalty indicator has a relatively desirable condition and has the same rank as e-service quality variable.

Due to the competitive environment in Iran in the field of electronic banking and the speed of technology development and of technology and the use of information in this field and according to perception of the results of this study indicating the importance of e-service quality in retaining customers and building confidence and loyalty leads to their satisfaction.

The following recommendations are offered in this regard. Improvement of information management and customer relationship management, using customer and users opinions to design bank website, to resolve user problems via phone and e-mail quickly, staff training to deal effectively with customers and solving their problems as the first priority, providing services available at any time and place. They should cover wider geographic areas and increase their credibility with customers. There should be a mechanism to audit the bank's computer system as it is done by the traditional form of bank branches to allow competent authorities to inspect electronic bank .In order to allow access and entering the system, the identity of people should be inspected before their login to system same as traditional banking that people can enter the system after they are inspected .Due to the possibility of fraud more in electronic systems than traditional systems the login processes must be constantly changing and progressing in order to avoid the login of jobbers. All transactions are inspected online and 24 hours to identify unauthorized events and to ensure data continuity. To improve the security / privacy of the website the following suggestions are offered:

To train technical personnel and systems developers frequently, to secure the system more, information and its transactions, policy making and legislation on personal data protection of users and prosecute violators, enabling users to monitor and control the collection', use, dissemination and access to information provided to the bank by other people, and give users choices about sharing personal information and using them in other areas, providing mechanisms for securing transactions, user information and notification mechanisms to enhance the high security (such as using the on-screen keyboard, password maintenance, PC security, etc).

Also to improve information quality of website the following suggestions offered:

Continuously update the information contained on the bank's website, the correct information and training on the products and services offered on the websites of banks, continuously inform the user of the account balance and their transaction condition, increasing number of promotion booths of e-service in branches to ease the applicants registration to use e-service website (such as receiving application ID, password, password finder, etc).

To increase and to improve website accountability, the following suggestions are offered:

To provide quick and high quality services to meet the needs, demands and expectations of users and to reduce the waiting time to get banking services, to identify user requirements and their feedback distribution across bank sectors, building a system of complaints and suggestions on the website.

Overall to increase satisfaction and to maintain customer and user loyalty the following suggestions are offered:

Continuous measurement of customer satisfaction in deadlines, to contact and to communicate with users and to monitor their satisfaction effectively through making a system of monitoring and measuring satisfaction on the website, to identify the factors of customer dissatisfaction who have cut their connection to the bank and its website or have reduced it. To analyze customers opinions and to do corrective measures based on findings.to increase users' positive experience by improving the quality and variety of services and to diversify them more, to provide programs in order to make customers loyal financially like giving privileges, special discounts or small gifts for those users who have more than a certain amount transactions a day, months or years through the transaction system. To have sortation periodically and to give awards to users who have the most numbers of Internet transactions during that period. To identify and to understand users' expectations and to make desirable expectations in users about the way of designing and providing services in website.

\section{References}

Abzari, M., Ghorbani, H., Khajezade, S., \& Makinian, E. (2011). Ranking of factors affecting confidence building in internet by using AHP technic. IT Management (AHP), 3(7), 1-18.

Al-Agaga, A. M., \& Nor, K. H. M. (2011). Factors that influence e-loyalty of internet banking users. International Conference on Internet Studies, September 8-10, Kuala Lumpur, Malaysia. 
Anderson, R., \& Srinivasan, S. S. (2003). E-Satisfaction and E-Loyalty: A Contingency Framework. Psychology \& Marketing, 20(2), 123-138. http://dx.doi.org/10.1002/mar.10063

Ariff, M. S. M., Yun, L. O., Zakuan, N., Ismail, \& Khalid. (2014). The Impacts of e-Service Quality and e-Customer Satisfaction on e-Customer Loyalty in Internet Banking. Advanced Science Letters, 20(1), 285-289. http://dx.doi.org/10.1166/asl.2014.5260

Auta, M. E. (2010). E-banking in developing economy: Empirical evidence from Nigeria. Journal of Applied Quantitative Methods, 5(2), 212-222.

Chang, H. H., \& Chen, S. W. (2008). The impact of customer interface quality, satisfaction and switching costs on e-loyalty: Internet experience as a moderator. Computers in Human Behavior, 24, 2927-2944. http://dx.doi.org/10.1016/j.chb.2008.04.014

Fragata \& Moustakas, E. (2012). Investigating Loyalty Determinants in Business Banking in Offline and Online Environments. 4th International Business and Social Science Research Conference, Dubai.

Gefen, D. (2000). E-commerce: the role of familiarity and trust. Department of management, LeBow College of Business, Drexel University, Philadelphia, USA.

Javanmard, H. A., \& Soltanzade, A. (2009). Investigation of internet brand and websites and its impact on customer confidence and loyalty (case study: Cultural products purchase via internet). Quarterly Journal of Commerce, 53, 256-225.

Li, Y. (2009). Measuring e-commerce dimensions. Journal of Computer Information Systems, 2-12.

Natchaya, C., \& Siriluck, R. (2010). Detemining the online purchasing loyalty for Tai Herbal Products. World Academy of Science, Engineering and Technology, 64, 453-456.

Olalekan. (2011). E-Banking Patronage in Nigeria: An Exploratory Study of Gender Difference. Business Intelligent Journal, 4(2), 243-252.

Reichheld, F. F. (1996). The Loyalty Effect. Boston, MA: Harvard Business School Press.

Yang, Z., Jun, M., \& Peterson, R. T. (2004). Measuring customer perceived online service quality: Scale development and managerial implications. International Journal of Operations \& Production Management, 24(11), 1149-1174. http://dx.doi.org/10.1108/01443570410563278

Yee, B. Y., \& Faziharudean, T. M. (2010). Factors Affecting Customer Loyalty of Using Internet Banking Malaysia. Journal of Electronic Banking Systems, 1-21. http://dx.doi.org/10.5171/2010.592297

Zahedi, S., \& Biniyaz, J. (2008). Assessing e-service quality of Raja Passenger trains. IT Management, 1(1), $82-65$.

\section{Copyrights}

Copyright for this article is retained by the author(s), with first publication rights granted to the journal.

This is an open-access article distributed under the terms and conditions of the Creative Commons Attribution license (http://creativecommons.org/licenses/by/3.0/). 